ORIGINAL ARTICLE / ARTIGO ORIGINAL

\title{
A portrait of risk behavior towards HIV infection among Brazilian Army conscripts by geographic regions, 2016
}

\author{
Retrato do comportamento de risco dos conscritos do Exército brasileiro à \\ infecção pelo HIV por macrorregiões brasileiras, 2016
}

Giseli Nogueira Damacena' (D), Célia Landmann Szwarcwald' (D), Leonardo Rapone da Motta" (1), Sérgio Kakuta Kato"II (1), Aline de Gregori Adamil (1), Machline Paim Paganella" (1), Gerson Fernando Mendes Pereiralv (D), Rosa Dea Sperhacke"l (1)

\begin{abstract}
Introduction: Knowledge about risky sexual behavior among young people has been widely acknowledged as a key tool to controlling the spread of HIV. This article aimed at presenting the risk behavior of Brazilian Army conscripts toward HIV infection according to the country's geographic regions. Method: We collected data from 37,282 conscripts, aged 17 to 22, during enlistment in the Brazilian Army in 2016. The prevalence of HIV infection, both self-reported and measured through laboratory results, and risk behavior factors were estimated by region. Results: $75 \%$ of the sample of conscripts reported to have already started sexual activity, and the average age of their sexual initiation was 15 . Condom use varied according to the type of sexual relationship, being lower among steady partners and greater among less stable relationships. HIV prevalence assessed by laboratory tests was $0.12 \%$ across the country and the highest prevalence was observed in the North region $(0.24 \%)$. Alcohol and illicit drug usage was higher in the South region. Discussion: The study allowed the observation of risk behavior monitoring for HIV infection among young Brazilians. Lower condom usage among steady partners may be contributing to an increase in the number of HIV-infected individuals. Conclusion: Results suggest the need to intensify prevention campaigns to disseminate safe sex practices among young people, in addition to the expansion of testing offer to this population.
\end{abstract}

Keywords: Military personnel. HIV. Risk behavior. Brazil.

Institute of Communication and Scientific Information and Technology in Health, Oswaldo Cruz Foundation- Rio de Janeiro (RJ), Brazil. "Laboratório de Pesquisa em HIV/Aids (LPHA), University of Caxias do Sul (UCS) - Caxias do Sul (RS), Brazil.

"'Graduate Program in Rehabilitation Sciences, Federal University of Health Sciences of Porto Alegre (UFCSPA) - Porto Alegre (RS), Brazil

IVDepartment of Chronic Conditions Diseases and Sexually Transmitted Infections, Secretariat of Health Surveillance, Ministry of Health - Brasília (DF), Brazil.

Corresponding author: Giseli Nogueira Damacena. Avenida Brasil, 4365, $2^{\circ}$ andar, sala 225, Manguinhos, Pavilhão Haity Moussatché, CEP 21040-900, Rio de Janeiro, RJ, Brazil. E-mail: damacenagn@gmail.com

Conflict of interests: nothing to declare - Financial support: Department of Chronic Conditions Diseases and Sexually Transmitted Infections, Secretariat of Health Surveillance, Ministry of Health of Brazil. 
RESUMO: Introdução: O conhecimento do comportamento sexual de risco entre jovens tem sido amplamente reconhecido como ferramenta-chave para controlar a propagação do HIV. Este artigo tem o objetivo de retratar o comportamento de risco dos conscritos do Exército brasileiro à infecção pelo HIV segundo as macrorregiões brasileiras. Métodos: Foram utilizados dados de 37.282 conscritos, entre 17 e 22 anos, durante apresentação ao Exército em 2016. Estimaram-se as prevalências de HIV autorreferida e medida por exame laboratorial, além de indicadores de comportamento de risco, por macrorregiões geográficas. Resultados: Dos conscritos que compuseram a amostra, $75 \%$ relatou já ter iniciado atividade sexual, e a média de idade de início foi de aproximadamente 15 anos. O uso do preservativo variou de acordo com o tipo de parceria sexual, sendo menor na relação com parceiros(as) fixos(as) e maior nas parcerias menos estáveis. A prevalência da infecção pelo HIV medida através do diagnóstico laboratorial foi de $0,12 \%$ no Brasil, sendo mais prevalente na região Norte $(0,24 \%)$. O consumo de álcool e drogas ilícitas foi maior na região Sul. Discussão: O estudo permitiu observar o monitoramento do comportamento de risco à infecção pelo HIV entre os jovens brasileiros. O menor uso de preservativo quando a parceria sexual é considerada estável pode estar contribuindo para aumentar o número de indivíduos infectados pelo HIV. Conclusão: Os resultados sugerem a necessidade de campanhas de divulgação para os jovens sobre práticas de sexo seguro, além da ampliação da oferta de testagem nessa população.

Palavras-chave: Militares. HIV. Comportamento de risco. Brasil.

\section{INTRODUCTION}

Since 1996 the Brazilian Department of Surveillance, Prevention and Control of Sexually Transmitted Infections, HIV / AIDS and Viral Hepatitis (DIAHV) of the Ministry of Health, in collaboration with the Brazilian Ministry of Defense has conducted probabilistic sample surveys to determine HIV prevalence, as well as to collect data on sexual and risk behaviors among Brazilian Army conscripts. The focus population was young men aged from 17 to 22 , in submission to compulsory military service. These studies generated prevalence information on sexually transmitted infections (STIs), as well as the monitoring of sexual risk behavior among Brazilian conscripts.

National and international surveys have indicated a greater vulnerability of adolescents and young men to STIs, particularly HIV infection ${ }^{1-4}$. In Brazil, data from the latest HIV/AIDS Epidemiological Bulletin ${ }^{5}$ indicated that, from 2007 to 2017the AIDS detection rate increased approximately 2.3 times among men aged 15 to 19 (from 3 to $7 / 100$ thousand inhabitants) and 20 to 24 (from 15.6 to $36.2 / 100$ thousand inhabitants). Studies to determine the factors involved in risky sexual behavior among young people have been recognized as key tools to control the spread of $\mathrm{HIV}^{6-9}$. These factors include the sexual practice between male partners, unprotected sex, the great multiplicity of sexual partnerships, and use of alcohol and drugs.

Brazil presents great geographic and cultural diversity, which is reflected in a highly heterogeneous HIV / AIDS epidemic. Brito et al. ${ }^{10}$ showed that when the HIV epidemic 
began in the 1980s, it was restricted to metropolises such as Rio de Janeiro and São Paulo, but since the 2000s it underwent a process of geographical internalization.

In this context, this article aims to portray the risk behavior of Brazilian Army conscripts toward HIV infection, by the Brazilian regions in 2016, as a continuation to the periodic monitoring studies of sexual behavior of Brazilian conscripts so as to subsidize HIV prevention programs.

\section{METHODS}

\section{SAMPLING}

We carried out a cross-sectional study with young men aged from 17 to 22 enlisted in the Brazilian Army, called conscripts, from August to December of 2016, throughout the country. To estimate the sample size, we recurred to the prevalence of HIV infection among young men in 2007 , which was estimated at $0.12 \%{ }^{3}$, with $95 \%$ of confidence interval and a bilateral error of $0.04 \%$. We selected a total of 39,996 conscripts by following a sampling plan with stratification in two selection stages. In the first stage we stratified the Selection Committees (SC) by the five Brazilian geographic regions and selected proportionally to each one's size, defined by the estimated frequency of conscripts who participated in the selection of 2014 . The sample thus obtained represented $6.2 \%$ of the total number of young men compulsorily enrolled in military service across the country. We chose 87 SC representing all the federative units (FU) of the country. During the second stage, we adjusted the number of conscripts to be proportional to each SC size. After applying all the exclusion criteria, the final sample consisted of 37,282 conscripts. The exclusion criteria were: illiterate conscripts; conscripts outside the established age range of 17 to 22 years old; lack of information on age, municipality of origin and educational level; and refusal to sign the Term of Free and Informed Consent (TFIC).

The project was approved by the Brazilian Commission for Research Ethics (CONEP), under registration no. 278,616, on May 21, 2013, and by the Research Ethics Committee of the University of Caxias do Sul, under registration number 1,074,338, on May 22, 2015, updated February 24, 2016, under registration No. 1,422,093.

The study followed the guidelines of the National Health Council, ensuring the voluntariness, anonymity and the possibility of interruption of participation at any time in the study, by signing the Term of Free Informed Consent TFIC.

\section{DATA COLLECTION AND LABORATORIAL TRIAL}

We collected socio-behavioral information through an anonymous and self-administered questionnaire, in order to guarantee the confidentiality of the information provided. We also 
collected blood samples for laboratory tests aimed at detecting HIV infections, syphilis and hepatitis B and C. And to detect HIV infection, which was fundamental for this article, we used the Elecsys HIV combi PT immunoassay (manufactured by Roche Diagnostics GmbH, in Penzberg, Germany). We classified non-reactive samples as HIV-negative, and no additional tests were performed, while samples with reactive results were subjected to the RealTime HIV-1 Viral Load Assay quantitative molecular test (manufactured by Abbott Molecular Inc., Des Plaines, Illinois, USA). Samples with a viral load of 5,000 copies $/ \mathrm{mL}$ or higher were classified as HIV positive, while samples with viral load equal to or less than 4,999 copies/ $\mathrm{mL}$ or below the detection limit of the assay were submitted to Western Blot New LAV Blot I (manufactured by Bio-Rad in Marnes-la-Coquette, France). Samples with positive Western Blot results were classified as positive; those with negative Western Blot were considered negative; and samples with indeterminate results were excluded from the analysis. All tests were performed according to the manufacturer's instructions by trained technicians and at a central laboratory in Vespasiano city, Minas Gerais, Brazil.

\section{VARIABLES OF THE STUDY}

In order to analyze the sample sexual behavior, we used the following information: percentage of informants who declared to have started their sexual activity; average age in the first intercourse; percentage of informants who reported having sex with men (MSM); average number of steady partners the previous year; percentage of condom use (in the last intercourse; all times with steady partners; all times with casual partners; all times while paying for sex). Conscripts who reported having had sex "only with men" and "with men and women" were classified as MSM.

Regarding the prevalence of HIV infection, we considered self-referral and laboratory exams presented by conscripts. We also considered the percentage that already knew their serological status for HIV infection among those identified as positive for HIV by the laboratory examination.

In order to characterize alcohol consumption we considered the percentages of conscripts that: (1) never used alcohol; have only tried it; did not use it anymore; (2) consumed it from time to time; and (3) consume it every day or almost every day.

With regard to illicit drugs, we measured the percentage on informants who used the following substances from time to time, every day or almost every day: cannabis, crack/merla / stone/ oxy/ cocaine snorted and injected, ecstasy. LSD; and the use of at least one of the above drugs (excluding cannabis and including heroin).

\section{DATA ANALYSIS}

All indicators were presented for the country (Brazil) as a whole and for each region (North, Northeast, Southeast, South and Central-West). The respective confidence intervals 
(95\%) were calculated taking into account the complex sampling design. Samples were compiled with Complex Samples add-on module included in SPSS 21.0 software ${ }^{11}$.

In addition, the percentage of condom use in all sexual intercourses with possible partners and prevalence of HIV infection diagnosed by laboratory examination were presented by UF, in the form of maps constructed from TerraView 4.2.2 software $^{12}$.

\section{RESULTS}

The study consisted of 37,282 conscripts aged 17 to 22, distributed in the five Brazilian regions as follows: Southeast (38.9\%); Northeast (30\%); South (13.9\%); North $(9.7 \%)$ and Central West (7.5\%). Table 1 shows the indicators related to sexual behavior according to each region.

The percentage that reported having started sexual life was $75 \%$ for Brazil, ranging from $71.9 \%$ in the North region and $81.5 \%$ in the Central-West region. The mean age of first sexual intercourse was approximately 15 for Brazil. Regarding the type of sexual partnership, $4.4 \%$ of the respondents declared to be MSM for Brazil, which ranged from $6.3 \%$ in the Southeast, $5.9 \%$ in the Central-West, and $2 \%$ in the North region, the lowest percentage found. Regarding the number of steady partners in the last year, conscripts registered 2.29 for Brazil and North reported the highest mean (3.20). As for individuals who reported having paid for sexual intercourse in the last year, the Southeast was the region with the highest percentage (3.7\%), exactly one point higher than the total in Brazil. Concerning condoms, approximately $61 \%$ reported use during the last sexual intercourse, being the lowest percentage (56.5\%) in the South region. As for condom use in all relationships with steady partners, the percentage for Brazil was 34.5\%, and lower in the South region $(29.6 \%)$. When sexual intercourse was with potential partners, use at all times increased to $45.6 \%$. In paid sex, about $69 \%$ of the participants reported using condoms in all relationships last year for Brazil, and the highest percentage was observed for the Northeast region $(75.1 \%)$.

The prevalence of HIV was presented under two perspectives: self-referenced and laboratory diagnosed (Table 2). We found differences for both Brazil and its regions, except for the Central-West. The self-reported prevalence for Brazil was $0.5 \%$, while the laboratory prevalence was $0.12 \%$. It is noteworthy the great difference found for the Southeast region: the self-reported prevalence was of $0.9 \%$ and the laboratory of only $0.07 \%$. Still on the HIV infection, the percentage of conscripts identified as positive in the laboratory examination who already knew they were infected by HIV for Brazil was of $5.1 \%$, and this percentage was even smaller number in the North region $(2.2 \%)$.

Table 2 also presents indicators on alcohol consumption and illicit drug use. Just over half of the participants reported never having consumed, have consumed only once or having stopped consumed alcohol (54\%). For the North region, the percentage is even higher, reaching almost $70 \%$ of conscripts. Among those who reported consuming alcohol from time to time, the highest consumption was observed in the South (59.7\%). Regarding the highest consumption of alcohol, those who reported consuming every day or almost every day for Brazil accounted for 
Table 1. Percentages of conscripts and confidence intervals (95\%) according to sexual behaviors by geographic distribution. Brazil, 2016.

\begin{tabular}{|c|c|c|c|c|c|c|c|c|c|c|}
\hline \multirow[b]{2}{*}{ Region } & \multirow[b]{2}{*}{$\begin{array}{l}\text { Sample } \\
\text { size }\end{array}$} & \multirow[b]{2}{*}{$\begin{array}{c}\text { Sexual } \\
\text { activity (\%) }\end{array}$} & \multirow[b]{2}{*}{$\begin{array}{l}\text { Mean age of } \\
\text { first sexual } \\
\text { intercourse }\end{array}$} & \multirow[b]{2}{*}{ MSM (\%) } & \multirow[b]{2}{*}{$\begin{array}{l}\text { Mean number of } \\
\text { partners in the } \\
\text { last year }\end{array}$} & \multirow{2}{*}{$\begin{array}{l}\text { Pay for } \\
\text { having sexual } \\
\text { intercourse in } \\
\text { the last year } \\
\text { (\%) }\end{array}$} & \multicolumn{4}{|c|}{ Condom use (\%) } \\
\hline & & & & & & & $\begin{array}{l}\text { In the last } \\
\text { sexual } \\
\text { intercourse }\end{array}$ & $\begin{array}{l}\text { All times with } \\
\text { steady partners }\end{array}$ & $\begin{array}{l}\text { All times with } \\
\text { occasional } \\
\text { partners }\end{array}$ & $\begin{array}{l}\text { All times } \\
\text { that had } \\
\text { paid sexual } \\
\text { intercourse }\end{array}$ \\
\hline \multirow{2}{*}{ North } & \multirow{2}{*}{$\begin{array}{l}3.607 \\
(9.7 \%)\end{array}$} & 71.9 & 14.56 & 2 & 3.20 & 2.9 & 66.5 & 42.1 & 48.8 & 64.8 \\
\hline & & $(68.1-75.5)$ & $(14.38-14.74)$ & $(1.3-3.1)$ & $(2.91-3.48)$ & $(1.9-4.4)$ & $(61.6-71)$ & $(36.5-47.9)$ & $(44.5-53.1)$ & $(60.4-68.9)$ \\
\hline \multirow{2}{*}{ Northeast } & \multirow{2}{*}{$\begin{array}{l}11.178 \\
(30 \%)\end{array}$} & 73.9 & 15.18 & 2.4 & 2.04 & 1.7 & 63 & 34.7 & 40.3 & 75.1 \\
\hline & & $(70.3-77.1)$ & $(15.05-15.31)$ & $(1.7-3.5)$ & $(1.79-2.29)$ & $(0.9-3.2)$ & $(58.5-67.2)$ & $(29-41)$ & (33.3-47.7) & $(66.9-81.9)$ \\
\hline \multirow{2}{*}{ Southeast } & \multirow{2}{*}{$\begin{array}{l}14.512 \\
(38.9 \%)\end{array}$} & 75 & 15.09 & 6.3 & 2.18 & 3.7 & 58.4 & 32.9 & 46.7 & 69.9 \\
\hline & & (72.3-77.5) & $(14.97-15.21)$ & $(4.6-8.8)$ & $(1.74-2.62)$ & $(2.7-5)$ & $(56-60.8)$ & $(30.2-35.7)$ & $(43-50.4)$ & $(63.6-75.5)$ \\
\hline \multirow{2}{*}{ South } & \multirow{2}{*}{$\begin{array}{c}5.177 \\
(13.9 \%)\end{array}$} & 76.2 & 14.97 & 4.3 & 2.10 & 2.1 & 56.5 & 29.6 & 46.1 & 60.5 \\
\hline & & $(71.6-80.2)$ & $(14.87-15.07)$ & $(2.6-7.1)$ & $(1.96-2.24)$ & $(1.2-3.7)$ & $(48.9-63.8)$ & $(26.2-33.2)$ & $(34.4-58.2)$ & $(47.1-72.5)$ \\
\hline \multirow{2}{*}{ Central-West } & \multirow{2}{*}{$\begin{array}{l}2.808 \\
(7.5 \%)\end{array}$} & 81.5 & 15.10 & 5.9 & 2.90 & 2.8 & 63.3 & 40.1 & 53.7 & 68 \\
\hline & & $(72.1-88.2)$ & $(14.99-15.21)$ & $(2.8-11.9)$ & $(2.09-3.71)$ & $(1.5-5.4)$ & $(57.6-68.6)$ & $(27.4-54.2)$ & (34.4-71.9) & $(62.9-72.8)$ \\
\hline \multirow{2}{*}{ Brazil } & \multirow{2}{*}{$\begin{array}{l}37.282 \\
(100 \%)\end{array}$} & 75 & 15.04 & 4.4 & 2.29 & 2.7 & 60.7 & 34.5 & 45.6 & 69.2 \\
\hline & & $(73.2-76.8)$ & $(14.97-15.12)$ & $(3.5-5.6)$ & $(2.08-2.51)$ & $(2.2-3.4)$ & $(58.5-62.8)$ & $(31.9-37.2)$ & $(42-49.4)$ & (65.3-72.8) \\
\hline
\end{tabular}


Table 2. Percentages of conscripts and confidence intervals (95\%) according to HIV prevalence, alcohol consumption and illicit drugs use by geographic distribution. Brazil, 2016.

\begin{tabular}{|c|c|c|c|c|c|c|c|c|c|c|c|}
\hline \multirow[b]{2}{*}{ Region } & \multicolumn{2}{|c|}{ HIV prevalence } & \multirow[b]{2}{*}{$\begin{array}{c}\text { Percentage of } \\
\text { conscripts already } \\
\text { award of their HIV } \\
\text { serological status }\end{array}$} & \multicolumn{3}{|c|}{ Alcohol comsumption (\%) } & \multicolumn{5}{|c|}{ Ilicit drug use once in a while, everyday or almost everyday (\%) } \\
\hline & $\begin{array}{c}\text { Self- } \\
\text { referenced }\end{array}$ & $\begin{array}{c}\text { Laboratoriy } \\
\text { diagnosed }\end{array}$ & & $\begin{array}{l}\text { Never/ } \\
\text { experimented } \\
\text { only or do not } \\
\text { use enymore }\end{array}$ & $\begin{array}{l}\text { Once in a } \\
\text { while }\end{array}$ & $\begin{array}{l}\text { Everyday } \\
\text { or almost } \\
\text { everyday }\end{array}$ & Cannabis & $\begin{array}{l}\text { crack/merla/ } \\
\text { stone/oxy } \\
\text { cocaine } \\
\text { snorted and } \\
\text { injected }\end{array}$ & Ecstasy & LSD & $\begin{array}{l}\text { At least one } \\
\text { drug (excluding } \\
\text { cannabis and } \\
\text { including } \\
\text { heronn) }\end{array}$ \\
\hline \multirow{2}{*}{ North } & 0.3 & 0.24 & 2.2 & 69.9 & 29.9 & 0.2 & 2.6 & 0.3 & 0.5 & 0.5 & 0.7 \\
\hline & $(0.13-0.70)$ & $(0.09-0.66)$ & $(0.4-11.7)$ & $(64.7-74.7)$ & $(25.2-35.1)$ & $(0.1-0.5)$ & $(1.9-3.6)$ & $(0.1-0.6)$ & $(0.1-1.4)$ & $(0.2-1.7)$ & $(0.3-1.5)$ \\
\hline \multirow{2}{*}{ Northeast } & 0.28 & 0.15 & 0 & 66.2 & 33.5 & 0.3 & 2.2 & 0.3 & 0.3 & 0.1 & 0.4 \\
\hline & $(0.11-0.69)$ & $(0.05-0.40)$ & - & $(61.5-70.6)$ & $(29-38.2)$ & $(0.1-0.7)$ & $(1.6-3.2)$ & $(0.1-0.9$ & $(0.1-0.9)$ & $(0.1-0.2)$ & $(0.2-0.9)$ \\
\hline \multirow{2}{*}{ Southeast } & 0.9 & 0.07 & 14.3 & 48.4 & 50.3 & 1.2 & 6.5 & 0.5 & 0.8 & 1.2 & 1.7 \\
\hline & $(041-1.94)$ & $(0.03-0.13)$ & $(1.9-58.9)$ & $(44.9-52)$ & $(46.9-53.7)$ & $(0.9-1.8)$ & $(5.4-7.8)$ & $(0.3-0.9)$ & $(0.5-1.4)$ & $(0.8-2)$ & $(1.2-2.4)$ \\
\hline \multirow{2}{*}{ South } & 0.24 & 0.10 & 6.4 & 38.1 & 59.7 & 2.2 & 9.7 & 0.8 & 2.4 & 2 & 3.1 \\
\hline & $(0.12-0.48)$ & $(0.04-0.20)$ & $(1.7-20.9)$ & $(34.6-41.7)$ & $(56.3-63)$ & $(1.7-2.9)$ & $(8-11.6)$ & $(0.4-1.5)$ & $(1.9-3)$ & $(1.5-2.6)$ & $(2.6-3.8)$ \\
\hline \multirow{2}{*}{ Central-West } & 0.13 & 0.13 & 8.7 & 44.5 & 53.3 & 2.2 & 4.2 & 0.8 & 0.5 & 0.9 & 1.4 \\
\hline & $(0.05-0.32)$ & $(0.04-0.40)$ & $(0.8-53.8)$ & $(37-52.2)$ & $(45-61.3)$ & $(1-5)$ & $(2.3-7.5)$ & $(0.3-1.9)$ & $(0.2-1.3)$ & $(0.4-2.2)$ & $(0.7-3)$ \\
\hline \multirow{2}{*}{ Brazil } & 0.5 & 0.12 & 5.1 & 54 & 44.9 & 1.1 & 5.1 & 0.5 & 0.8 & 0.9 & 1.4 \\
\hline & $(0.28-0.90)$ & $(0.07-0.19)$ & $(1.3-17.5)$ & $(51-57)$ & $(42-47.8)$ & $(0.8-1.4)$ & $(4.4-6)$ & $(0.4-0.7)$ & $(0.6-1.1)$ & $(0.7-1.3)$ & $(1.1-1.8)$ \\
\hline
\end{tabular}


$1.1 \%$ of the total sample, and for the South and Central-West regions this percentage doubled $(2.2 \%)$. With regard to illicit drug use, cannabis was the most consumed, with the percentages of $5.1 \%$ for Brazil and $9.7 \%$ for the South region. Still on this region we observed that it presented the highest percentage of use for the other drugs reported. Referring to the use of at least one illicit drug (excluding cannabis and including heroin) we observed $1.4 \%$ reported use in Brazil, and the South region with the highest percentage (3.1\%).

We observe in Figure 1 the distribution by FU of the percentage of condom use in all sexual intercourses with eventual partners in the last year and the prevalence of HIV infection diagnosed in laboratory examination. The FUs which presented condom use of less than $40 \%$ in sexual intercourse with eventual partners were: Maranhão, Bahia, Federal District, Mato Grosso do Sul and Santa Catarina. In addition, most FUs presented a percentage of condom use ranging from 40 to $49.9 \%$. Figure 1 also shows that the highest prevalence of HIV infection was in the North region, for the FUs of Pará, Amapá, Amazonas and Roraima presented a prevalence of $2 \%$ or more, as well as the FUs of Ceará, Espírito Santo and the Federal District, that compose other regions.

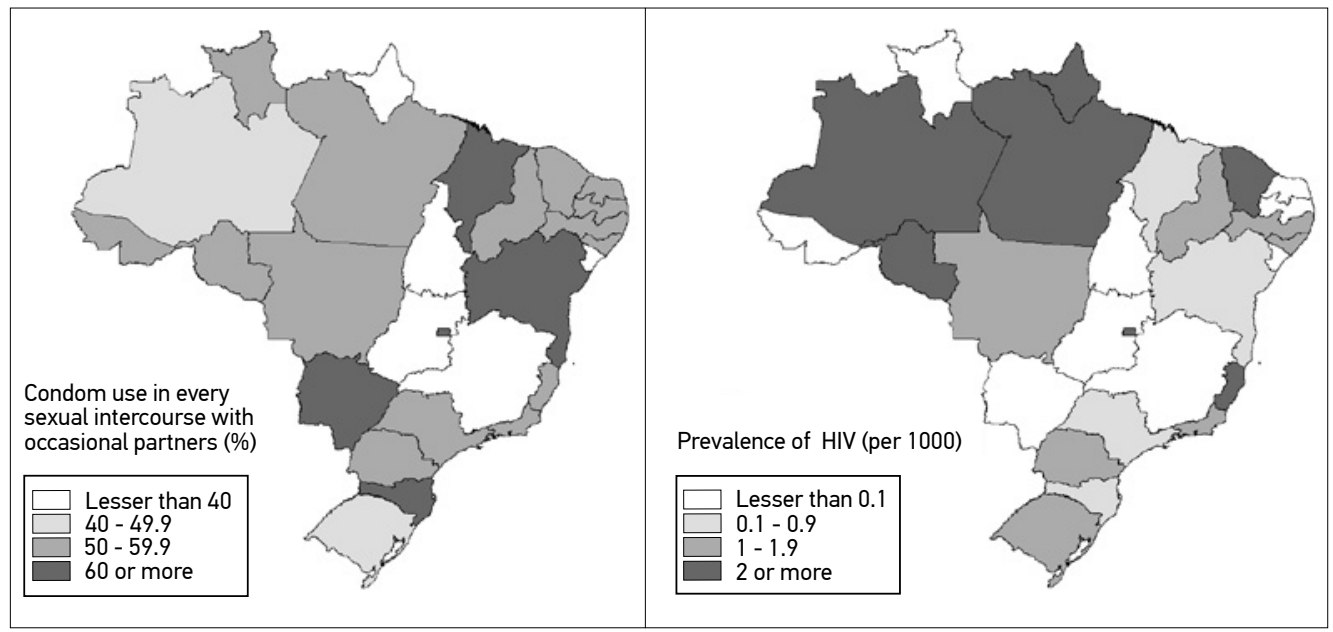

Figure 1. Percentages of condom use in all sexual intercourses with casual partners and HIV infection prevalence assessed by laboratory assays during the survey by Federative Unit. Brazil, 2016.

\section{DISCUSSION}

Since 1996 the Ministry of Health and the Ministry of Defense have been jointly carrying out a series of actions at national level with young conscripts of the Army when they enroll in military service, which is a legal obligation of young men when they reach 18 years of age. Such actions have been extremely important for the monitoring of indicators essential to health surveillance in this population. Nine years after the last survey, in 2016 a new data 
collection was carried out to observe the behavior of Brazilian young people, including the risky practices concerning HIV infection.

However, it is necessary to highlight some limitations of researches with conscripts. The first one refers to the exclusion criteria, by which the illiterates, those whose questionnaires do not inform age, municipality of origin and educational level are excluded from the study. The second is related to the collection of social-behavioral information through a self-completion questionnaire. Self-completion facilitates truthfulness in answers that could be embarrassing if they were asked by an interviewer. On the other hand, some important information may be inconsistent if the respondent does not understand the questions. Nonetheless, the use of standardized instruments for data collection and laboratory measurements, the size of the sample studied and the design applied minimize the limitations described.

The beginning of sexual activity has occurred increasingly earlier among young people and is a important moment in their lives, as it places them in a world of new discoveries and, at the same time, in a possible group of vulnerability to STIs ${ }^{13} .75 \%$ of the conscripts participating in the study had already begun his sexual life, and the mean age of beginning was 15 . Early sexual initiation exposes the adolescent to a context of vulnerability to HIV infection and other STIs, as he/she will have a long period of sexual activity and more sexual partners until he/she reaches stable and durable monogamous relationships in a more mature phase of 1 ife ${ }^{13-15}$. Studies have identified association between early beginning of sexual life by and increased risk factor for acquiring $\mathrm{STI}^{16}$. In addition, studies emphasize the relationship between the behavior adopted at the first sexual intercourse and practices that may persist throughout the individual's life, especially regarding the use of condoms ${ }^{17,18}$.

Results indicate that the use of condoms clearly goes through the sexual intercourses established by the Brazilian conscripts, since the proportion of use in all sexual intercourses increases as trust on the sexual partner decreases. This proportion of use is lower when the partner is steady, increases when it is a occasional partner, and gets even greater when the conscript pays to have sex. This pattern is the same for all geographic regions, and we found in the Northeast region the greatest difference between the proportions of condom use in the most conservative relationship - with steady partners - and in the most vulnerable relationship, with paid partners.

It is important to emphasize that the concept of a steady partner was not defined by the researchers, leaving to the interviewee's understanding what he considered to be a steady partnership. However, studies show that the sexual intercourse with a steady partner, often considered as a stable relationship, decreases the perception of risk, bringing a false sense of protection against STIs and consequently decreasing the use of condoms $\mathrm{s}^{3,15}$. In addition, in heterosexual relationships the focus becomes the prevention of pregnancy, so that the use of other contraceptive methods between the couple overlaps the use of condom ${ }^{19}$. In this context, the problem is when one of the partners is unknowingly infected with some STI without symptoms, causing the transmission to his/her current 
partner ${ }^{20}$, either because of previous sexual intercourses with other partners or because of extramarital relationships, both without a condom ${ }^{21}$. This false security behavior in a considered stable partnership may be contributing to the increase in the number of young Brazilians infected with HIV.

Under the same view of the partnerships considered conservative, the North region presented the highest mean of steady partners in the last year, one of the highest percentage of conscripts who paid to have sexual intercourses in the last year and the highest percentage of use of a condom in the last sexual intercourse. This indicates that, the greater the number of partners in the year, the lower is the confidence of being in a "safe" sexual relationship and, consequently, the greater the chance that the condom will be used in those relationships. This corroborating the result that condom use is lower in relationships considered stable, the North region presented the highest average number of steady partners and the highest HIV prevalence.

One of the indicators used in global reports of the World Health Organization to measure the prevalence of condom use is its use in the last sexual relationship ${ }^{22}$. The data from this study indicated a prevalence of condom use in the last sexual intercourse above $56 \%$ in all regions, a consistent result to the percentage found in a survey of Brazilian youth aged $15-24$ years including both sexes $(60 \%)^{17}$.

In recent years, research has pointed to the acceleration of the advance of HIV in Brazil, especially in MSM. The present study pointed out that $4.4 \%$ of young conscripts that reported being MSM, the highest percentage observed in the Southeast region. Statistically, the chance of an MSM becoming infected with HIV is greater than the chance of a man in a heterosexual relationship ${ }^{23}$, since there are fewer potential partners and a high proportion of people affected, therefore the likelihood of having sexual intercourse with someone infected with HIV and getting infected is higher. As the epidemic spreads in this minority, the risk of infection increases for those who are not infected, in a vicious cycle. A survey conducted in 12 Brazilian capitals in 2016 found that $18.4 \%$ of MSM surveyed were infected with HIV. The survey was conducted among MSM aged 18 years and over, $58.3 \%$ of them younger than 25 years of age ${ }^{24}$. Sperhacke et al. ${ }^{1}$ identified that in 2016 the prevalence of HIV among Brazilian conscripts who declared themselves as MSM was $1.32 \%$, while for the total sample the prevalence was $0.12 \%$.

Prevalence of diseases is useful to formulate and evaluate public policies. Self-reported measures are commonly used because they are easy to collect and do not require specific health training or additional cost. However, this measurement process can lead to skewed measures. In the comparison of self-reported HIV prevalence with laboratory-measured prevalence, differences of 0.38 percentage points were found for Brazil, and the highest was 0.83 in the Southeast region. As the survey is conducted during the military service enrollment process and the questionnaire is self-administered, one hypothesis to explain the large differences between HIV prevalence found between the two methods of measurement is that, while the study ensured the confidentiality of information, some conscripts, with the 
intention of being discharged from military service, might have given incorrect information about having certain diseases, especially HIV.

The highest prevalence of HIV infection (through laboratory diagnosis) was found in the North region $(0.24 \%)$. According to data from the HIV/AIDS Epidemiological Bulletin ${ }^{25}$, the North region presented a linear trend of growth of the HIV detection rate between 2006 and 2015: it was 15 to 24 cases / 100 thousand inhabitants, representing an increase of $61.4 \%$. And in the ranking of the FU and capitals according to the index composed of the indicators of rates of detection, mortality and first CD4 count, the FU of Amazonas and the city of Manaus (the state capital) are in first place.

The South region presented the highest percentages of alcohol and illicit drug use. As risk behaviors, alcohol and drug use constitute proved facilitators of HIV infection ${ }^{26}$, and may be contributing to the advancement of the HIV epidemic among the general population of the South region, especially in the FU of Rio Grande do Sul, which present high detection rates of HIV $^{5}$.

The low percentage of conscripts who already knew their serological status among those identified as positive in the laboratory examination indicate low coverage of HIV testing among the Brazilian male youth population, making it difficult to combat the spread of HIV, since the virus can be transmitted by individuals who do not know their serological status.

\section{CONCLUSION}

Results of the study suggest that there is a need for greater investment in sex education and safe sex practices campaigns, warning young people that the cure for HIV and other STIs infections are yet to be found. Despite the possibility of controlling STIs, it is a mistake to believe that people can get rid of them. Once STIs are established, the quality of life of the patients becomes compromised. In addition, there is a need to expand the supply of HIV testing, as the test enables early diagnosis and immediate treatment, reducing the chances of dissemination of the virus.

\section{REFERENCES}

1. Sperhacke RD, da Motta LR, Kato SK, Vanni AC, Paganela MP, Oliveira MCP, et al. HIV prevalence and sexual behavior among young male conscripts in the Brazilian army, 2016. Medicine. 2018;97(1S Suppl 1):S2531. https: / / doi.org/10.1097/MD.0000000000009014

2. da Motta LR, Sperhacke RD, Adami AG, Kato SK, Vanni AC, Paganella MP, et al. Syphilis prevalence and risk factors among young men presenting to the
Brazilian Army in 2016: results from a national survey. Medicine. 2018;97(47):e13309. https:/ / dx.doi.org/ 10.1097/MD.0000000000013309

3. Szwarcwald CL, de Andrade CLT, Pascom ARP, Fazito E, Pereira GFM, Penha IT. HIV-related risky practices among Brazilian young men, 2007. Cad Saúde Pública. 2011;27(Suppl 1):S19-26. http:/ / dx.doi.org/10.1590/S0102-311X2011001300003 
4. Szwarcwald CL, Carvalho MF, Barbosa Júnior A, Barreira D, Speranza FAB, Castilho EA. Temporal trends of HIV-related risk behavior among Brazilian Military Conscripts, 1997-2002. Clinics. 2005;60(5):367-74. http:// dx.doi.org/10.1590/ S1807-59322005000500004.

5. Brasil. Ministério da Saúde. Secretaria de Vigilância em Saúde. Departamento de Vigilância, Prevenção e Controle das Infecções Sexualmente Transmissíveis, do HIV/ Aids e das Hepatites Virais. Boletim Epidemiológico HIV/AIDS [Internet]. Brasília, DF; 2018 [cited 2019 Jan 2];49(53). Available from: http:/ / www.aids.gov.br/pt-br/pub/2018/ boletim-epidemiologico-hivaids-2018.

6. Fonte VRF, Spindola T, Francisco MTR, Sodré CP, André NLNO, Pinheiro CDP. Jovens universitários e o conhecimento acerca das infecções sexualmente transmissíveis. Esc Anna Nery. 2018;22(2):e20170318. http: / / dx.doi.org/10.1590/2177-9465-EAN-2017-0318

7. Guimarães MDC, Kendall C, Magno L, Rocha GM, Knauth DR, Leal AF, et al. Comparing HIV risk-related behaviors between 2 RDS national samples of MSM in Brazil, 2009 and 2016. Medicine. 2018;97(1S Suppl 1)S:62-S68. https:/ / doi.org/10.1097/ MD.0000000000009079

8. United Nations Programme on HIV/AIDS. Global AIDS Monitoring 2018: indicators for monitoring the 2016 United Nations Political Declaration on Ending AIDS [Internet]. Viena; 2017 [cited 2019 Jan 2]. 155 p. Available from: http: / / bit.ly/2YBPUZc

9. Saengdidtha B, Rangsin R, Kaoaiem H, Sathityudhakarn O. Risk factors for HIV infection among Thai young men aged 21-23 years. Epidemiology. 2016;6:3. https: / / dx.doi.org/10.4172/2161-1165.1000248

10. Brito AM, Castilho EA, Szwarcwald CL. Aids e infecção pelo HIV no Brasil: uma epidemia multifacetada. Rev Soc Bras Med Trop. 2001;34(2):207-17. http:/ / dx.doi. org/10.1590/S0037-86822001000200010

11. IBM SPSS Statistics for Windows. Version 21.0 [software]. Armonk, NY: IBM Corp; 2012.

12. Instituto Nacional de Pesquisas Espaciais (BR). TerraView 4.2.2 [software]. São José dos Campos; 2013. Available from: www.dpi.inpe.br/terraview

13. Teixeira A, Knauth DR, Fachel JMG, Leal AF. Adolescentes e uso de preservativos: as escolhas dos jovens de três capitais brasileiras na iniciação e na última relação sexual. Cad Saúde Pública.
2006; 22(7):1385-96. http:/ / dx.doi.org/10.1590/ S0102-311X2006000700004.

14. Ma Q, Ono-Kihara M, Cong L, Pan X, Xu G, Zamani $S$, et al. Behavioral and psychosocial predictors of condom use among university students in Eastern China. AIDS Care. 2009;21(2):249-59. https: / / doi.org/ 10.1080/09540120801982921

15. Berquó E, Barbosa RM, Lima LP. Uso do preservativo: tendências entre 1998 e 2005 na população brasileira. Rev Saúde Pública. 2008;42(Suppl 1):34-44. http:/ / dx.doi.org/10.1590/S0034-89102008000800006

16. Milhausen RR, McKay A, Graham CA, Crosby RA, Yarber WL, Sanders SA, et al. Prevalence and predictors of condom use in a national sample of Canadian university students. Can J Hum Sex. 2013;22(3):142-51. https://doi.org/10.3138/cjhs.2316

17. Calazans G, Araujo TW, Venturi G, França Junior I. Factors associated with condom use among youth aged 15-24 years in Brazil in 2003. AIDS. 2005;19(Suppl 4):S42-50.

18. Hugo TDO, Maier VT, Jansen K, Rodrigues CEG, Cruzeiro ALS, Ores LC, et al. Fatores associados à idade da primeira relação sexual em jovens: estudo de base populacional. Cad Saúde Pública. 2011;27(11):2207-14. http:/ / dx.doi.org/10.1590/ S0102-311X2011001100014

19. Delatorre MZ, Dias ACG. Conhecimentos e práticas sobre métodos contraceptivos em estudantes universitários. Rev da SPAGESP. 2015;16(1):60-73.

20. Centers for Disease Control and Prevention (EUA). Condoms and STDs: fact sheet for public health personnel. Atlanta: CDC; 2010.

21. Maia C, Guilhem D, Freitas D. Vulnerabilidade ao HIV/Aids de pessoas heterossexuais casadas ou em união estável. Rev Saúde Pública. 2008;42(2):242-48. http:/ / dx.doi.org/10.1590/S0034-89102008005000004

22. World Health Organization, Joint United Nations Programme on HIV/AIDS. Global AIDS response progress reporting 2015. Geneva: WHO; 2015.

23. Beyrer C, Baral SD, van Griensven F, Goodreau SM, Chariyalertsak S, Wirtz AL, et al. Global epidemiology of HIV infection in men who have sex with men. Lancet. 2012;380(9839):367-77. https: / / doi.org/10.1016/S0140-6736(12)60821-6

24. Kerr L, Kendall C, Guimarães MDC, Salani Mota R, Veras MA, Dourado I, et al. HIV prevalence among men who have sex with men in Brazil: results of 
the second national survey using respondent-driven sampling. Medicine. 2018;97(S1):e10573. https:// doi.org/10.1097/MD.0000000000010573

25. Brasil. Ministério da Saúde. Secretaria de Vigilância em Saúde. Departamento de Vigilância, Prevenção e Controle das Infecções Sexualmente Transmissíveis, do HIV / Aids e das Hepatites Virais. Boletim Epidemiológico HIV/AIDS [Internet]. Brasília, DF; 2016 [cited 2019 Jan 2];5(1). Available from: http: / /www.aids.gov.br/pt-br/pub/2016/ boletim-epidemiologico-de-aids-2016

26. Pereira Bde S, Costa MC, Amaral MT, da Costa HS, da Silva CA, Sampaio VS. Factors associated with HIV/AIDS infection among adolescents and young adults enrolled in a Counseling and Testing Center in the State of Bahia, Brazil. Ciên Saúde Colet. 2014;19(3):747-58. http: / dx.doi.org/ $10.1590 / 1413-81232014193.16042013$
Received on: 01/02/2019

Final version presented on: 22/05/2019

Approved on: 27/05/2019

Acknowledgments: To all conscripts who participated in the study and to the team that developed the research. We also thank the Department of Chronic Conditions Diseases and Sexually Transmitted Infections of the Ministry of Health; and the Brazilian Army.

Authors' contribution: Damacena GN and Sperhacke RD conceived the manuscript. Text was writen by Adami AG, Damacena GN, Kato SK, Motta LR, Paganella MP, Sperhacke RD e Szwarcwald CL. Kato SK conducted data collection, which were analyse by Damacena GN e Szwarcwald CL. Adami AG revised the text and translated items written in English, besides participating in the operationalization of the research. Motta has coordinated the laboratorial research Pereira GFM contributed to gather funding. Sperhacke RD coordinated the study. All authors revised and approved the final version of the article. 